\title{
Influence of Light Emitting Diode (LED) on Microalgae
}

\author{
Sajjad K. Al-amshawee ${ }^{1,{ }^{*}}$ and Mohd Yusri M. Yunus ${ }^{1,2}$
}

${ }^{1}$ Faculty of Chemical and Process Engineering Technology, Universiti Malaysia Pahang, 26300 Gambang, Pahang, Malaysia. 2Earth Resource and Sustainability Centre (ERAS), Universiti Malaysia Pahang, 26300 Gambang, Pahang, Malaysia.

\begin{abstract}
There are 150,000 microalgae species. Scientists identified and classified 30,000 species. Only 10-15 species are utilised and studied for wastewater treatment, biogas upgrading, biomass production, and lipid content. LED can raise microalgae performance to the highest. Therefore, numerous empirical investigations have discussed for years about using various circumstances like light intensity, dark: light ratio, and wavelength. Though, studies have not discovered the ultimate LED for achieving maximum growth. Thus, this mini-review article shows the recent conducted studies on various microalgae species under LED impact to discover a range of optimal conditions. Besides, future perspective presents the next stage of research and development on using LED for microalgae growth.
\end{abstract}

\section{KEYWORDS}

Microalgae growth

LED intensity

LED wavelength

Biogas upgrading

Wastewater treatment

\section{MICROALGAE}

The global consumption of crude oil is 80-90 million barrels of oil per day from the 1.3 trillion barrels worldwide reserves which lead to depletion of crude oil reserves within less than 50 years (Abdullah et al., 2007). Also, there is a compulsive need for sustainable methods to stop the caused disasters by industrial activities like climate change and global warming. Recently, microalgae have been recognised as an eco-friendly treatment for $\mathrm{CO}_{2}$ capture, wastewater mediation, bioactive compounds resource (e.g., sterols, vitamins, fatty acids, carotenoids), and bioenergy production (e.g., syngas, biomethane, biohydrogen, bioethanol, biodiesel) (Bibi et al., 2017; Jankowska et al., 2017; Ringsmuth et al., 2016; Salam et al., 2016; Thangavelu et al., 2016). Their global sustainability, diversity, and availability make them perfect microorganisms for a renewable source of energy. Also, they can double their biomass within $3.5 \mathrm{~h}$, which is $5-$ 10 times faster than terrestrial biomass (Khan et al., 2009; Severes et al., 2017). They live in marine water, saltwater, freshwater, and on the surfaces of wet rocks or soils. Microalgae can be cultured in nutrient-rich wastewater which reduces the required chemical nutrients (Jayakumar et al., 2017; Pawar, 2016; Piloto-Rodríguez et al., 2017; Salam et al., 2016). Utilizing microalgae can benefit the nature by reducing $\mathrm{CO}_{2}$ footprint and increasing $\mathrm{O}_{2}$. Despite that, there are tens of thousands of algae unculturable. Before 2000 years, the Chinese utilised the microalgae to survive from food shortage (Hsia \& Yang, 2015). During the second world war, the first scientific work was conducted on microalgae.

Algae classification is based by the cell walls composition, the stored carbohydrate type, and the pigments sort for the photosynthesis such as cyanobacteria (red-green algae), brown algae, red algae (Rhodophyta), diatoms (Bacillariophyta), and green algae (Chlorophyta) (Baicha et al., 2016). From 150,000 microalgae species, there are only 30,000 microalgae had been classified based on their metabolism or cell wall, pigments, size, or colour (Glemser et al., 2016).

Microalgae possess pigments and chlorophyll for processing photosynthesis by capturing sunlight as their source of energy with $182.88 \mathrm{~m}$ (600 ft.) candles saturation limit. The chlorophyll absorbs blue and red spectra with a maximum range of $425 \mathrm{~nm}$ and $665 \mathrm{~nm}$ from the visible light range (380-750 nm), respectively. Photosynthesis process converts light energy into chemical energy like complex sugar (carbohydrate), and starch. For that, it can be defined as a microscopic photosynthetic organism. They are a diverse group of eukaryotic and prokaryotic photosynthetic microorganisms with simple multicellular or unicellular structure that allows them to develop fast and survive in harsh circumstances and non-arable land (Baicha et al., 2016). The simple structure of microalgae performs photosynthesis process to transform light energy into chemical energy rapidly, and it is more efficient than crop plants. Additionally, they simultaneously use $\mathrm{CO}_{2}$ and nutrients as substrates for their growth and produce half the atmospheric oxygen (Ugwu et al., 2008).

Microalgae growth is dependent on essential factors such as darkness, irradiance, temperature, photoperiod, light intensity, salinity, mixing, aeration system, nutrient composition, $\mathrm{pH}, \mathrm{CO}_{2}$ levels, culture depth and density, and natural or artificial light (Vanags et al., 2015; Wahidin et al., 2013).

Photobioreactors employed as enclosed reactors for microalgae growth and development for wastewater mediation with the ability to control the reactor temperature (see figure 1) (Kaewpintong et al., 2007; Pulz, 2001). Despite that, stabilisation ponds (open microalgae ponds) are more efficient and economical than photobioreactor for domestic sewage treatment because of their low energy consumption, high removal efficiency, and low maintenance and construction cost. 
Though, it is worth noting that photooxidation and light inhibition highly occur in microalgae open ponds (Ferrero et al., 2012; Severes et al., 2017; Xin et al., 2010).

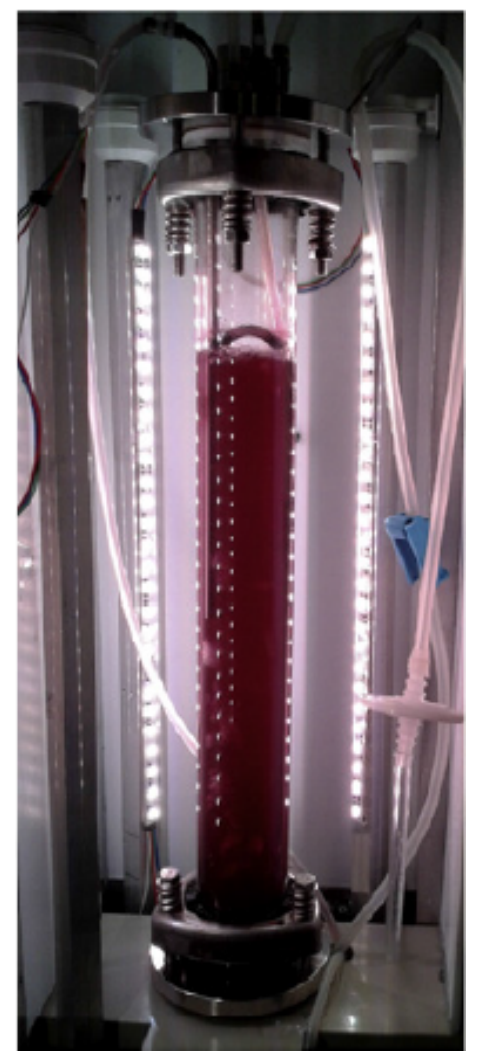

Figure 1. An image of a photobioreactor [adopted from (Baer et al., 2016)].

In 1942, sorts of microalgae were suggested as feasible food, source of lipids or oil producers (Baicha et al., 2016). Then, studies had investigated the physiology and biology of the microalgae at the beginning of the 1960s. During the oil crisis in the 1970s, microalgae got immense interest to replace fossil fuels.

Many researchers investigated microalgae under different circumstances because of microalgae demands for optimal conditions during wastewater treatment. Studies reported that microalgae suffer from inappropriate light wavelength and intensity (Pilon et al., 2011; Wang et al., 2007). Excessive irradiance at noontime (hot summer) or insufficient light energy on a rainy day causes photoinhibition and reduces microalgae photosynthesis (Pilon et al., 2011; Ugwu et al., 2007). Also, high-density microalgae culture requires high light intensity to deliver sufficient energy to all microalgae cells. The maximum removal of wastewater nutrients is achievable by supplying ideal lighting conditions (Di Termini et al., 2011). Thus, researchers still investigate microalgae culturing on different lighting sources.

Artificial lighting is more preferred than sunlight because it is controllable and applicable to specific waves and colours. Then, narrowband lights like LED reported as more efficient, durable, cheap, long life, reliable, and economical than fluorescent lamps and ordinary light bulbs. Non-narrow band lights deliver a combination of efficient and inefficient light spectra which can harm microalgae cells and affect the photosynthesis performance and may not contain the bands of chlorophyll pigments (Amer et al., 2011; Cheirsilp \& Torpee, 2012; Y. J. Zhao et al., 2011). Thus, it can deliver low production, light shortage, and photoinhibition. Different sorts of microalgae may demand various light wavelengths and intensities. Therefore, illumination is a critical factor.

\section{LIGHT EMITTING DIODE (LED)}

Light wavelength is an essential component for microalgae culture development (Yan \& Zheng, 2014). LED had shown high performance of providing the optimal spectra for various microalgae species and being cost-effective, narrowband wavelength, and controllable in terms of intensity and length. Despite that, cell pigments, function, size, and shape are the main criteria that control light absorption. In microalgae culturing, the highest energy consumption is caused by the illumination, where it works 24 hours inside the photobioreactor. LED does not radiate heat as other lighting types, which protects microalgae cultures from overheating (Hulata, 2010). Also, their easy installation, low energy consumption, and being small structures made them eco-friendly.

Microalgae growth is manipulatable by supplying a monochromatic LED (Hultberg et al., 2014). For instance, the red LED enhances Cholera Vulgaris photosystem II, while the blue LED improves photosystem I (Ravelonandro et al., 2008; You \& Barnett, 2004). In years ago, a report showed that the red LED improves microalgae cell generation, but it is less efficient than blue light for biomass production (Chen et al., 2009; Hulata, 2010). Despite that, blue light increases 
microalgae oil production by transforming more carbon amount per day for every cell with the highest respiration rate (Shu et al., 2012).

Thick microalgae culture reflects, refracts, and absorbs different spectra inside photobioreactor, so, it is a substantial challenge to control dense culture (see Figure 2). In another case, too high light intensity (photons $1 / \mathrm{m}^{2} . \mathrm{s}$ ) is unusable by microalgae cells because of being higher than the active photosynthetic radiation range and leads to photooxidation, photoinhibition, photo saturation, and even damage microalgae cells. However, using high intensity was an ideal condition for high dense cultures. A researcher reported that a red LED with $1000 \mu \mathrm{mole} / \mathrm{m}^{2}$.s intensity is the optimal mono lighting system for biogas upgrading (Yan et al., 2016). It delivered TP, TN, COD, and $\mathrm{CO}_{2}$ removal of $57.08 \% \pm$ $5.69,57.21 \% \pm 5.56,66.48 \% \pm 5.44$, and $57.33 \% \pm 5.62$, while a blue LED delivered lower removal rates, respectively. Another study had confirmed that the red LED is the best choice for methane gas upgrading (Zhao et al., 2013). The red LED with intensity of $2000 \mu \mathrm{mole} / \mathrm{m}^{2} . \mathrm{s}$ achieved COD, TN, and TP reduction of $85.35 \% \pm 1.04,77.98 \% \pm 1.84$, and $73.03 \% \pm 2.14$, respectively and $92.74 \% \pm 3.56$ methane upgrading. However, when the intensity of the red LED was changed into 400 and $2400 \mu \mathrm{mole} / \mathrm{m}^{2} . \mathrm{s}$, or a blue LED was used, it delivered the lowest performance.

A study examined six different wavelengths illumination impact on Chlorella vulgaris (Hultberg et al., 2014). The examination found that the green light gave the lowest lipid concentration among the other ranges. In contrast, another investigation showed that the green LED with intensity of $100 \mu \mathrm{mole} / \mathrm{m}^{2} . \mathrm{s}$ could provide the highest lipid generation from Nannochloropsis oculate, Nannochloropsis salina, and Nannochloropsis oceanica among red, yellow, blue, purple, and fluorescent illumination for two days (Ra et al., 2016). Another empirical work tested another species of microalgae known as Chlorella Kessleri (UTEX 398) in photobioreactor under fluorescent light, blue LED, and red LED (Hulata, 2010). Blue LED had generated the greatest range of various cells, while the red LED produced the highest cell number with the highest weight.

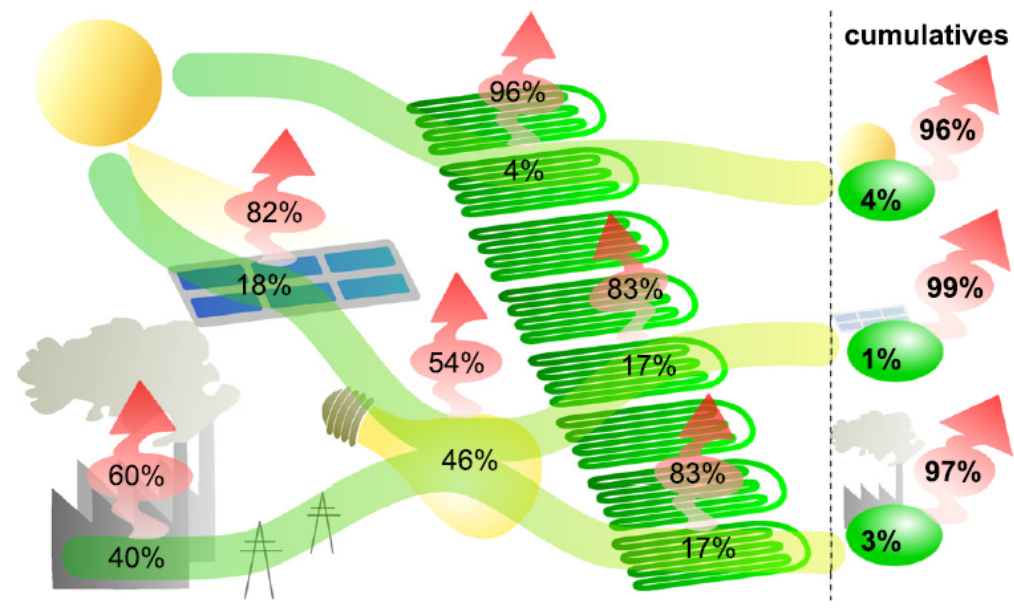

Figure 2. Overview of the energy balance by different energy sources [adopted from (Blanken et al., 2013)].

Yanting. et al. (2017) found that blue LED produced the highest lipid content ( $13.76 \%$ and $31.18 \%$ of dry cell weight) from Chlorella Vulgaris and Ankistrodesmus Falcatus. The examination was conducted at $60 \mu \mathrm{mole} / \mathrm{m}^{2} . \mathrm{s}$ intensity, 25 ${ }^{\circ} \mathrm{C}$, and 16h:8h light and dark cycle for 12 days (Yanting et al., 2017). Chlorella vulgaris was investigated for 8 days under blue LED with different dark: light ratios and intensities (Atta et al., 2013). The maximum lipid content (23.5\%) was accomplished at $12 \mathrm{~h}: 12 \mathrm{~h}$ of light: dark and $200 \mu \mathrm{mole} / \mathrm{m}^{2} . \mathrm{s}$ intensity. The success of blue LED was a result of well deep light penetration and high efficiency, while white fluorescent light delivered 20.9\% lipid content at 8h:16h of Dark: light for 10 days.

A researcher had employed different ranges of a blue-red LED of 1:9, 3:7, 5:5, 7:3, 9:1 for upgrading biogas quality by microalgae treatment with intensity of $800 \mu \mathrm{mole} / \mathrm{m}^{2}$.s (Yan \& Zheng, 2014). The ratio of red: blue of 5:5 proved being the optimal ratio for nutrients removal and biogas upgrading, where it enhanced $\mathrm{CH}_{4}$ concentration from $65 \%$ to 93.68\% and reduced $\mathrm{CO}_{2}$ concentration from $34 \%$ to $1 \%$ at $120 \mathrm{~h}$. Also, it removed $\mathrm{CO}_{2}, \mathrm{COD}, \mathrm{TN}$, and TP of $57.73 \% \pm$ $5.14,56.13 \% \pm 6.32,52.89 \% \pm 7.04$, and $48.51 \% \pm 7.69 \%$, respectively. Thus, blue and red LED could accomplish high microalgae performance by delivering sufficient light wavelengths for the photosynthesis process and satisfying the microalgae of the required light energy. In another research, Haematococcus lacustris, and Astaxanthin gave the best growth performance of $84.12 \mathrm{mg} / \mathrm{L}$ and biomass of $3.28 \mathrm{~g} \mathrm{~L}^{-1}$ under red-blue LED of 1:3 with intensity of $160 \mu \mathrm{mole} / \mathrm{m}^{2} . \mathrm{s}$ (Tran et al., 2015).

Baer et al. (2016) conducted a significant examination of different microalgae species growth (Baer et al., 2016). The conduction showed that the highest biomass productivity for Prophyridium Purpureum, Galdieria Sulphuraria, and Chlamydomonas Reinhardtii is approachable at blue: green: red of 20:40:40, pure red light, or blue: green: red of 10:10:80.

Mixing of the photobioreactor medium was employed by Kunjapur (2010) to increase microalgae exposure to light and decrease dark rate which consequently led to high biomass production, and mass transfer between cells and nutrients (Vanags et al., 2015). 
A study had tested the impact of various intensities of 50, 100 and $200 \mu \mathrm{mole} / \mathrm{m}^{2}$.s with light-dark ratio of $24 \mathrm{~h}: 0 \mathrm{~h}$, 18h:06h, and 12h:12h on Nannochloropsis sp. growth for eight days (Wahidin et al., 2013). The maximum growth was $0.3391 / \mathrm{d}$ with $31.3 \%$ lipid content under $18 \mathrm{~h}: 6 \mathrm{~h}$ of light: dark ratio and $100 \mu \mathrm{mole} / \mathrm{m}^{2} . \mathrm{s}$ intensity.

In a different study, Schulze et al. (2017) had reviewed a flashing LED (i.e. pulsing light) to boost microalgae growth (Schulze et al., 2017). It was assumed that sending a short light period with high intensity could be adequate for the photosynthesis and perform deep light penetration. Figure 3 presents the application of pulsing and continuous light on microalgae growth.

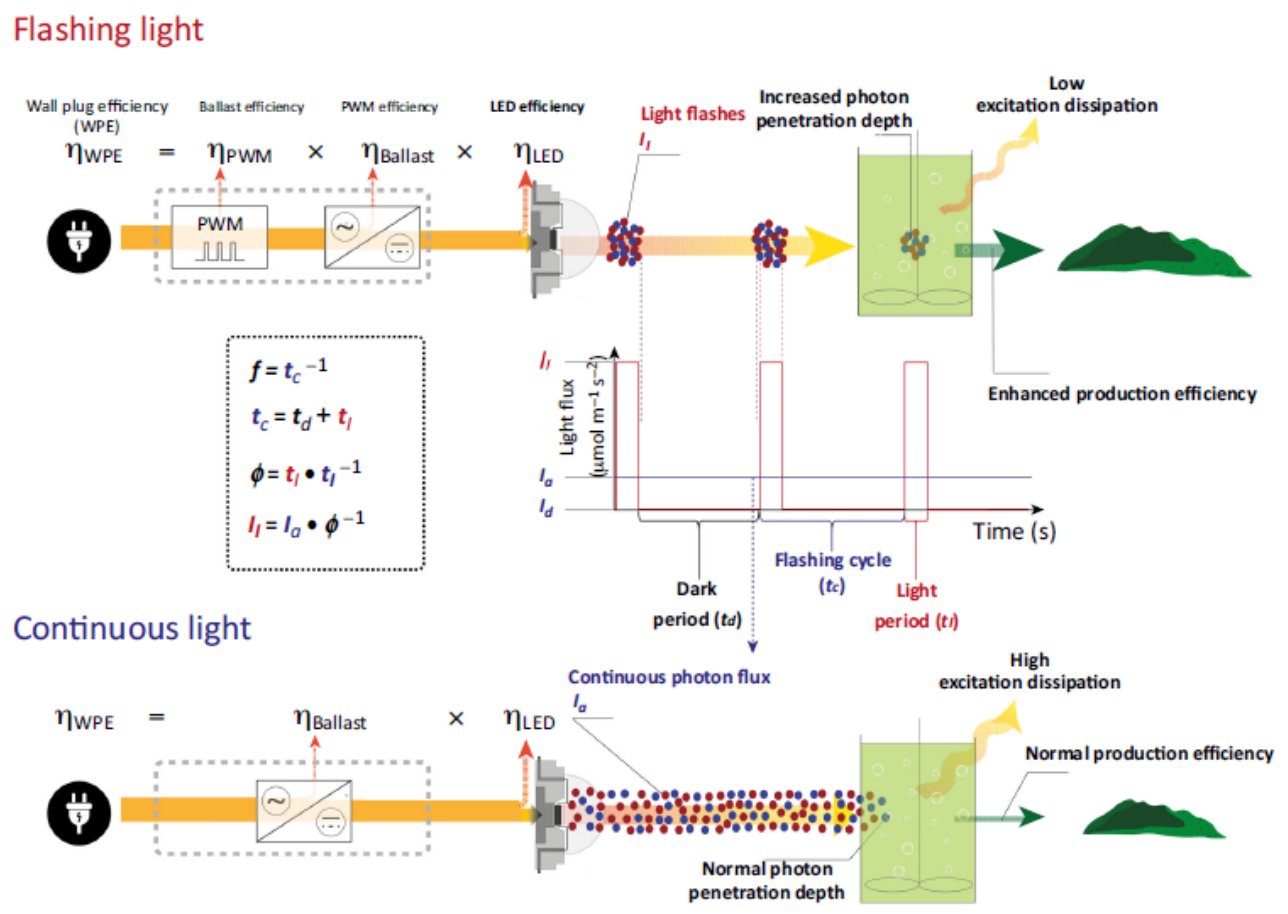

Figure 3. Scheme of Pulse and continuous light impact on microalgae process [adopted from (Schulze et al., 2017)].

Red, white, yellow, purple, blue, and green LEDs were employed to examine their influence on Chlorella Vulgaris microalgae for domestic wastewater treatment for $144 \mathrm{hr}$ (Yan, Zhang, et al., 2013). Various intensities were used in different durations for four stages as following: $1000 \mu \mathrm{mole} / \mathrm{m}^{2} . \mathrm{s}$ intensity for $0-48 \mathrm{~h}, 1500 \mu \mathrm{mole} / \mathrm{m}^{2}$.s intensity for $48-$ $96 \mathrm{~h}, 2000 \mu \mathrm{mole} / \mathrm{m}^{2}$.s intensity for $120-144 \mathrm{~h}$, and finally $2500 \mu \mathrm{mole} / \mathrm{m}^{2} . \mathrm{s}$ intensity for $96-120 \mathrm{~h}$. Red LED with 620 $630 \mathrm{~nm}$ wavelength had shown the best performance for domestic wastewater treatment characterized by different concentrations of $\mathrm{C} / \mathrm{N}$. Another study examined various intensities at particular increments on Chlorella Vulgaris, where stage 1 is $0-48 \mathrm{~h}$ at $800 \mu \mathrm{mole} / \mathrm{m}^{2}$.s intensity, stage 2 is $48-96 \mathrm{~h}$ at $1200 \mu \mathrm{mole} / \mathrm{m}^{2}$.s intensity, and stage 3 is $96-144 \mathrm{~h}$ at $1600 \mu \mathrm{mole} / \mathrm{m}^{2}$.s intensity (Yan, Zhao, et al., 2013). Red light characterized by $660 \mathrm{~nm}$ wavelength delivered greater performance than green, blue, purple, yellow, and white light by removing maximum amounts of $82.19 \% \pm 6.71 \mathrm{COD}$, $69.29 \% \pm 5.17 \mathrm{TN}$, and $77.24 \% \pm 4.92 \mathrm{TP}$.

Khalili et al. (2015) found that warm white light resulted in superior treatment compared to the red LED, blue LED, and natural white light performance for producing maximum Chlorella Vulgaris biomass (Khalili et al., 2015).

Meanwhile, Vanags et al. (2015) examined the growth of Desmodesmus Communis under illumination, aeration, and shaking (Vanags et al., 2015). Effect of shaking, aeration and light increased the productivity and yield of biomass to 0.54 $\mathrm{g} / \mathrm{d}$ and $3.53 \mathrm{~g} / \mathrm{L}$, respectively.

An idea was introduced for painting fluorescent lights to manipulate illumination intensity. Besides, it is cheap and readily available. Seo et al. (2014) proposed that paints can convert UV waves into usable visible light (Seo et al., 2014). The proposed idea was conducted empirically and obtained $1.7 \mathrm{~g} / \mathrm{L}$ maximum growth with $30 \%$ lipid content.

Another research proposed using Nanoscale coating filter as selective transmit for specific wavelengths (Ramanna et al., 2017). The nanoscale coating could be placed on glass or plastic substrates, where plastic is more preferred than glass because of being versatile, flexible, and sufficient thickness. The coating system could protect microalgae from photoinhibition, and photooxidation by reflecting infrared waves, and UV rays.

Researchers used high intensity to defeat dense cultures and accomplish well light penetration. Although, they neglected pigments and chlorophyll absorption limit, and the high intensity might cause photoinhibition, photooxidation, and hurting cells (see Figure 4). Researchers achieved slightly different results even with using the same LED light, intensity, wavelength, and dark: light duration due to photobioreactor design and size, microalgae population, temperature, and dominant species. Different microalgae require various circumstances to deliver the optimal performance, but so far, most of the discussed studies agree on using the red LED for lipid content production, cell generation, $\mathrm{CO}_{2}$ reduction, and biogas upgrading, while the blue LED is recommended for biomass production. 


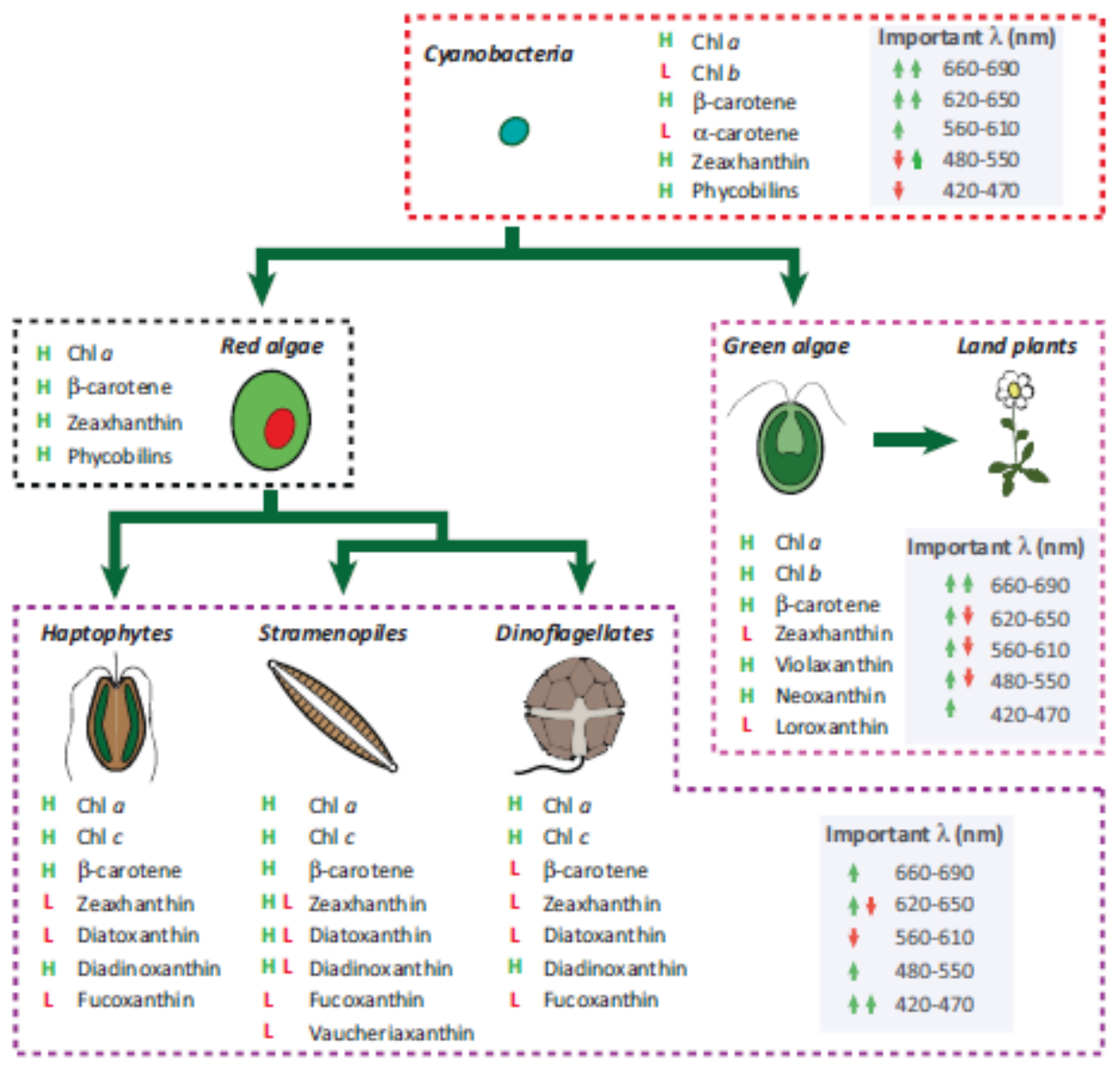

Figure 4. Intensity ranges of various microalgae species [adopted from (Schulze et al., 2014)].

\section{FUTURE PERSPECTIVE AND CHALLENGES}

Numerous things still require research and development. Currently, most of the scientific researches are occurring on Chlorella Vulgaris, although none has named it as the perfect microorganism among the 150,000 microalgae species. Thus, it is still a long way to discover the most appropriate microalgae species for wastewater treatment, biogas upgrading, lipid production, and biomass generation. Besides, researchers are highly interested in figuring out the optimal conditions for microalgae growth from temperature, light type, intensity, dark: light ratio, aeration, mixing, flashing light, shaking, sunlight, warm or cold light, and graduated intensities.

\section{CONCLUSION}

Researchers need thousands of years to examine every single microalgae species among the 150,000 species. Thus, common parameters (e.g., pigments, chlorophyll, and ability to upgrade biogas content, treat wastewater, produce biomass, generate lipid) have been identified to examine various microalgae species. However, empirical studies are still investigating microalgae performance under different circumstances.

Researchers have been debating on using different wavelengths, intensities, and dark: light ratio. Some have neglected the effect of temperature and LED distance from the species, which possibly cause cell damage. Although, most of the researchers had agreed on using the blue light for biomass production, and the red light for cell generation, $\mathrm{CO}_{2}$ decay, biogas upgrading, and lipid content production but within acceptable intensity (below $2000 \mu \mathrm{mole} / \mathrm{m}^{2} . \mathrm{s}$ ). Then, many researchers had worked on using multi-colour LED to achieve microalgae satisfaction of light energy.

Despite that, research and development have not stopped and found out that using shaking, mixing, aeration, incremental phases of intensities, and warm light with multi-waves LED can increase microalgae efficacy to the maximum. Due to very few types of research on these parameters, it is impossible to decide a precise rate for accomplishing optimal growth.

\section{ACKNOWLEDGMENT}

This article was introduced and composed by Sajjad Al-Amshawee. The corresponding author gratefully acknowledges the enormous support of Dr. Yusri Yunus for supervising this study. 
This research work is financially supported by the Fundamental Research Grant Scheme (FRGS/UMP.05/26.12/04/01/1) with the RDU number RDU190160 which is awarded by the Ministry of Higher Education Malaysia (MOHE) via Research and Innovation Department, Universiti Malaysia Pahang (UMP) Malaysia. Thanks to Institute of Postgraduate Studies, Universiti Malaysia Pahang for awarding the corresponding author a Doctoral Research Scheme.

\section{REFERENCES}

Abdullah, A. Z., Razali, N., Mootabadi, H., \& Salamatinia, B. (2007). Critical technical areas for future improvement in biodiesel technologies. Environmental Research Letters, 2(3), 034001. https://doi.org/10.1088/17489326/2/3/034001

Amer, L., Adhikari, B., \& Pellegrino, J. (2011). Technoeconomic analysis of five microalgae-to-biofuels processes of varying complexity. Bioresource Technology, 102(20), 9350-9359. https://doi.org/10.1016/j.biortech.2011.08.010

Atta, M., Idris, A., Bukhari, A., \& Wahidin, S. (2013). Intensity of blue LED light: A potential stimulus for biomass and lipid content in fresh water microalgae Chlorella vulgaris. Bioresource Technology, 148, 373-378. https://doi.org/10.1016/j.biortech.2013.08.162

Baer, S., Heining, M., Schwerna, P., Buchholz, R., \& Hübner, H. (2016). Optimization of spectral light quality for growth and product formation in different microalgae using a continuous photobioreactor. Algal Research, 14, $109-115$. https://doi.org/10.1016/j.algal.2016.01.011

Baicha, Z., Salar-García, M. J., Ortiz-Martínez, V. M., Hernández-Fernández, F. J., de los Ríos, A. P., Labjar, N., Lotfi, E., \& Elmahi, M. (2016). A critical review on microalgae as an alternative source for bioenergy production: A promising low cost substrate for microbial fuel cells. Fuel Processing Technology, 154(August 2016), $104-116$. https://doi.org/10.1016/j.fuproc.2016.08.017

Bibi, R., Ahmad, Z., Imran, M., Hussain, S., Ditta, A., Mahmood, S., \& Khalid, A. (2017). Algal bioethanol production technology: A trend towards sustainable development. In Renewable and Sustainable Energy Reviews (Vol. 71, pp. 976-985). https://doi.org/10.1016/j.rser.2016.12.126

Blanken, W., Cuaresma, M., Wijffels, R. H., \& Janssen, M. (2013). Cultivation of microalgae on artificial light comes at a cost. Algal Research, 2(4), 333-340. https://doi.org/10.1016/j.algal.2013.09.004

Cheirsilp, B., \& Torpee, S. (2012). Enhanced growth and lipid production of microalgae under mixotrophic culture condition: Effect of light intensity, glucose concentration and fed-batch cultivation. Bioresource Technology, 110, 510-516. https://doi.org/10.1016/j.biortech.2012.01.125

Chen, P., Min, M., Chen, Y., Wang, L., Li, Y., Chen, Q., Wang, C., Wan, Y., Wang, X., Cheng, Y., Deng, S., Hennessy, K., Lin, X., Liu, Y., Wang, Y., Martinez, B., \& Ruan, R. (2009). Review of the biological and engineering aspects of algae to fuels approach. In International Journal of Agricultural and Biological Engineering (Vol. 2, Issue 4, pp. 1-30). https://doi.org/10.3965/j.issn.1934-6344.2009.04.001-030

Di Termini, I., Prassone, A., Cattaneo, C., \& Rovatti, M. (2011). On the nitrogen and phosphorus removal in algal photobioreactors. Ecological Engineering, 37(6), 976-980. https://doi.org/10.1016/j.ecoleng.2011.01.006

Ferrero, E. M., de Godos, I., Rodríguez, E. M., García-Encina, P. A., Muñoz, R., \& Bécares, E. (2012). Molecular characterization of bacterial communities in algal-bacterial photobioreactors treating piggery wastewaters. Ecological Engineering, 40, 121-130. https://doi.org/10.1016/j.ecoleng.2011.10.001

Glemser, M., Heining, M., Schmidt, J., Becker, A., Garbe, D., Buchholz, R., \& Brück, T. (2016). Application of lightemitting diodes (LEDs) in cultivation of phototrophic microalgae: current state and perspectives. Applied Microbiology and Biotechnology, 100(3), 1077-1088. https://doi.org/10.1007/s00253-015-7144-6

Hsia, S. Y., \& Yang, S. K. (2015). Enhancing Algal Growth by Stimulation with LED Lighting and Ultrasound. Journal of Nanomaterials, 2015. https://doi.org/10.1155/2015/531352

Hulata, G. (2010). The Open Access Israeli Journal of Aquaculture - Bamidgeh Editor-in-Chief Use of Red and Blue Light-Emitting Diodes ( LED ) and Fluorescent Lamps to Grow Microalgae in a Photobioreactor. The Israeli Journal of Aquaculture, January.

Hultberg, M., Jönsson, H. L., Bergstrand, K. J., \& Carlsson, A. S. (2014). Impact of light quality on biomass production and fatty acid content in the microalga Chlorella vulgaris. Bioresource Technology, 159, $465-467$. https://doi.org/10.1016/j.biortech.2014.03.092

Jankowska, E., Sahu, A. K., \& Oleskowicz-Popiel, P. (2017). Biogas from microalgae: Review on microalgae's cultivation, harvesting and pretreatment for anaerobic digestion. In Renewable and Sustainable Energy Reviews (Vol. 75, pp. 692-709). https://doi.org/10.1016/j.rser.2016.11.045

Jayakumar, S., Yusoff, M. M., Rahim, M. H. A., Maniam, G. P., \& Govindan, N. (2017). The prospect of microalgal biodiesel using agro-industrial and industrial wastes in Malaysia. In Renewable and Sustainable Energy Reviews (Vol. 72, pp. 33-47). https://doi.org/10.1016/j.rser.2017.01.002

Kaewpintong, K., Shotipruk, A., Powtongsook, S., \& Pavasant, P. (2007). Photoautotrophic high-density cultivation of vegetative cells of Haematococcus pluvialis in airlift bioreactor. Bioresource Technology, 98(2), $288-295$. https://doi.org/10.1016/j.biortech.2006.01.011

Khalili, A., Najafpour, G. D., Amini, G., \& Samkhaniyani, F. (2015). Influence of nutrients and LED light intensities on biomass production of microalgae Chlorella vulgaris. Biotechnology and Bioprocess Engineering, 20(2), $284-290$. 
https://doi.org/10.1007/s12257-013-0845-8

Khan, S. A., Rashmi, Hussain, M. Z., Prasad, S., \& Banerjee, U. C. (2009). Prospects of biodiesel production from microalgae in India. Renewable and Sustainable Energy Reviews, 13(9), $2361-2372$. https://doi.org/10.1016/j.rser.2009.04.005

Pawar, S. (2016). Effectiveness mapping of open raceway pond and tubular photobioreactors for sustainable production of microalgae biofuel. In Renewable and Sustainable Energy Reviews (Vol. 62, pp. 640-653). https://doi.org/10.1016/j.rser.2016.04.074

Pilon, L., Berberoĝlu, H., \& Kandilian, R. (2011). Radiation transfer in photobiological carbon dioxide fixation and fuel production by microalgae. In Journal of Quantitative Spectroscopy and Radiative Transfer (Vol. 112, Issue 17, pp. 2639-2660). https://doi.org/10.1016/j.jqsrt.2011.07.004

Piloto-Rodríguez, R., Sánchez-Borroto, Y., Melo-Espinosa, E. A., \& Verhelst, S. (2017). Assessment of diesel engine performance when fueled with biodiesel from algae and microalgae: An overview. In Renewable and Sustainable Energy Reviews (Vol. 69, pp. 833-842). https://doi.org/10.1016/j.rser.2016.11.015

Pulz, O. (2001). Photobioreactors: Production systems for phototrophic microorganisms. In Applied Microbiology and Biotechnology (Vol. 57, Issue 3, pp. 287-293). https://doi.org/10.1007/s002530100702

Ra, C. H., Kang, C. H., Jung, J. H., Jeong, G. T., \& Kim, S. K. (2016). Effects of light-emitting diodes (LEDs) on the accumulation of lipid content using a two-phase culture process with three microalgae. Bioresource Technology, 212, 254-261. https://doi.org/10.1016/j.biortech.2016.04.059

Ramanna, L., Rawat, I., \& Bux, F. (2017). Light enhancement strategies improve microalgal biomass productivity. Renewable and Sustainable Energy Reviews, 80(June 2016), 765-773. https://doi.org/10.1016/j.rser.2017.05.202

Ravelonandro, P. H., Ratianarivo, D. H., Joannis-cassan, C., \& Raherimandimby, M. (2008). Influence of light quality and intensity in the cultivation of Spirulina platensis from Toliara (Madagascar) in a closed system. In Journal of Chemical Technology \& Biotechnology (Vol. 848, pp. 842-848). https://doi.org/10.1002/jctb

Ringsmuth, A. K., Landsberg, M. J., \& Hankamer, B. (2016). Can photosynthesis enable a global transition from fossil fuels to solar fuels, to mitigate climate change and fuel-supply limitations? In Renewable and Sustainable Energy Reviews (Vol. 62, pp. 134-163). https://doi.org/10.1016/j.rser.2016.04.016

Salam, K. A., Velasquez-Orta, S. B., \& Harvey, A. P. (2016). A sustainable integrated in situ transesterification of microalgae for biodiesel production and associated co-products - A review. In Renewable and Sustainable Energy Reviews (Vol. 65, pp. 1179-1198). https://doi.org/10.1016/j.rser.2016.07.068

Schulze, P. S. C., Barreira, L. A., Pereira, H. G. C., Perales, J. A., \& Varela, J. C. S. (2014). Light emitting diodes (LEDs) applied to microalgal production. Trends in Biotechnology, 32(8), $422-430$. https://doi.org/10.1016/j.tibtech.2014.06.001

Schulze, P. S. C., Guerra, R., Pereira, H., Schüler, L. M., \& Varela, J. C. S. (2017). Flashing LEDs for Microalgal Production. Trends in Biotechnology, xx, 1-14. https://doi.org/10.1016/j.tibtech.2017.07.011

Seo, Y. H., Cho, C., Lee, J.-Y., \& Han, J.-I. (2014). Enhancement of growth and lipid production from microalgae using fluorescent paint under the solar radiation. Bioresource Technology, 173, $193-197$. https://doi.org/10.1016/j.biortech.2014.09.012

Severes, A., Hegde, S. S., D’Souza, L., \& Hegde, S. S. (2017). Use of light emitting diodes (LEDs) for enhanced lipid production in micro-algae based biofuels. Journal of Photochemistry and Photobiology B: Biology, 170(September 2016), 235-240. https://doi.org/10.1016/j.jphotobiol.2017.04.023

Shu, C. H., Tsai, C. C., Liao, W. H., Chen, K. Y., \& Huang, H. C. (2012). Effects of light quality on the accumulation of oil in a mixed culture of Chlorella sp. and Saccharomyces cerevisiae. Journal of Chemical Technology and Biotechnology, 87(5), 601-607. https://doi.org/10.1002/jctb.2750

Thangavelu, S. K., Ahmed, A. S., \& Ani, F. N. (2016). Review on bioethanol as alternative fuel for spark ignition engines. In Renewable and Sustainable Energy Reviews (Vol. 56, pp. 820-835). https://doi.org/10.1016/j.rser.2015.11.089

Tran, H. L., Lee, K. H., \& Hong, C. H. (2015). Effects of LED irradiation on the growth and Astaxanthin Production of Haematococcus lacustris. Biosciences Biotechnology Research Asia, 12(2), 1167-1173. https://doi.org/10.13005/bbra/1769

Ugwu, C. U., Aoyagi, H., \& Uchiyama, H. (2007). Influence of irradiance, dissolved oxygen concentration, and temperature on the growth of Chlorella sorokiniana. Photosynthetica, 45(2), 309-311. https://doi.org/10.1007/s11099-007-0052-y

Ugwu, C. U., Aoyagi, H., \& Uchiyama, H. (2008). Photobioreactors for mass cultivation of algae. In Bioresource Technology (Vol. 99, Issue 10, pp. 4021-4028). https://doi.org/10.1016/j.biortech.2007.01.046

Vanags, J., Kunga, L., Dubencovs, K., Galvanauskas, V., Balode, M., \& Grigs, O. (2015). The Effect of Shaking, CO2 Concentration and Light Intensity on Biomass Growth of Green Microalgae Desmodesmus communis. Environmental Research, Engineering and Management, 70(4), 73-79. https://doi.org/10.5755/j01.erem.70.4.8437

Wahidin, S., Idris, A., \& Shaleh, S. R. M. (2013). The influence of light intensity and photoperiod on the growth and lipid content of microalgae Nannochloropsis sp. Bioresource Technology, 129, 7-11. https://doi.org/10.1016/j.biortech.2012.11.032

Wang, C. Y., Fu, C. C., \& Liu, Y. C. (2007). Effects of using light-emitting diodes on the cultivation of Spirulina platensis. Biochemical Engineering Journal, 37(1), 21-25. https://doi.org/10.1016/j.bej.2007.03.004

Xin, L., Hong-ying, H., Ke, G., \& Jia, Y. (2010). Growth and nutrient removal properties of a freshwater microalga Scenedesmus sp. LX1 under different kinds of nitrogen sources. Ecological Engineering, 36(4), 379-381. 
https://doi.org/10.1016/j.ecoleng.2009.11.003

Yan, C., Muñoz, R., Zhu, L., \& Wang, Y. (2016). The effects of various LED (light emitting diode) lighting strategies on simultaneous biogas upgrading and biogas slurry nutrient reduction by using of microalgae Chlorella sp. Energy, 106, 554-561. https://doi.org/10.1016/j.energy.2016.03.033

Yan, C., Zhang, L., Luo, X., \& Zheng, Z. (2013). Effects of various LED light wavelengths and intensities on the performance of purifying synthetic domestic sewage by microalgae at different influent $\mathrm{C} / \mathrm{N}$ ratios. Ecological Engineering, 51, 24-32. https://doi.org/10.1016/j.ecoleng.2012.12.051

Yan, C., Zhao, Y., Zheng, Z., \& Luo, X. (2013). Effects of various LED light wavelengths and light intensity supply strategies on synthetic high-strength wastewater purification by Chlorella vulgaris. Biodegradation, 24(5), 721732. https://doi.org/10.1007/s10532-013-9620-y

Yan, C., \& Zheng, Z. (2014). Performance of mixed LED light wavelengths on biogas upgrade and biogas fluid removal by microalga Chlorella sp. Applied Energy, 113, 1008-1014. https://doi.org/10.1016/j.apenergy.2013.07.012

Yanting, Z., Fang, D., \& Peng, J. (2017). Effects of Light-emitting Diodes (LEDs) on the Accumulation of Lipid Content in Microalgae. International Conference on Sustainable Energy and Environment Protection (ICSEEP 2017), Icseep. https://doi.org/10.1016/j.biortech.2016.04.059

You, T., \& Barnett, S. M. (2004). Effect of light quality on production of extracellular polysaccharides and growth rate of Porphyridium cruentum. Biochemical Engineering Journal, 19(3), $251-258$. https://doi.org/10.1016/j.bej.2004.02.004

Zhao, Y. J., Hui, Z., Chao, X., Nie, E., Li, H. J., He, J., \& Zheng, Z. (2011). Efficiency of two-stage combinations of subsurface vertical down-flow and up-flow constructed wetland systems for treating variation in influent $\mathrm{C} / \mathrm{N}$ ratios of domestic wastewater. Ecological Engineering, $37(10), \quad$ 1546-1554. https://doi.org/10.1016/j.ecoleng.2011.06.005

Zhao, Y., Wang, J., Zhang, H., Yan, C., \& Zhang, Y. (2013). Effects of various LED light wavelengths and intensities on microalgae-based simultaneous biogas upgrading and digestate nutrient reduction process. Bioresource Technology, 136, 461-468. https://doi.org/10.1016/j.biortech.2013.03.051 